\title{
M-RAS Regulate CDH1 Function in Blastomere Compaction during Porcine Embryonic Development
}

\author{
Dongjie Zhou, Yingjie Niu and Xiang-Shun Cui* \\ Department of Animal Science, Chungbuk National University, Cheongju 28644, Korea
}

Received February 14, 2020

Revised March 11, 2020

Accepted March 11, 2020

*Correspondence

Xiang-Shun Cui

E-mail: xscui@cbnu.ac.kr

ORCID

https://orcid.org/0000-0001-6180-6401

\begin{abstract}
Cell adhesion plays an important role in the differentiation of the morphogenesis and the trophectoderm epithelium of the blastocyst. In the porcine embryo, $\mathrm{CDH} 1$ mediated adhesion initiates at compaction before blastocyst formation, regulated post-translationally via protein kinase $C$ and other signaling molecules. Here we focus on muscle RAS oncogene homolog (M-RAS), which is the closest relative to the RAS related proteins and shares most regulatory and effector interactions. To characterize the effects of M-RAS on embryo compaction, we used gain- and loss-offunction strategies in porcine embryos, in which M-RAS gene structure and protein sequence are conserved. We showed that knockdown of M-RAS in zygotes reduced embryo development abilities and $\mathrm{CDH} 1$ expression. Moreover, the phosphorylation of ERK was also decreased in M-RAS KD embryos. Overexpression of M-RAS allows $M-R A S$ KD embryos to rescue the embryo compaction and blastocyst formation. Collectively, these results highlight novel conserved and multiple effects of M-RAS during porcine embryo development.
\end{abstract}

Keywords: blastocyst formation, $\mathrm{CDH} 1$, embryo compaction, muscle RAS oncogene homolog (M-RAS)

\section{INTRODUCTION}

M-Ras shares $\sim 50 \%$ sequence identity with the canonical Ras proteins (Kimmelman et al., 1997), and, although it can interact with some of the well-established Ras effectors, such as Raf, PI3K, and RalGDS. M-Ras also binds to distinct effectors, including certain RapGEFs and the Shoc2 scaffold (Herrmann et al., 1996; Rebhun et al., 2000; Gao et al., 2001; Rodriguez-Viciana et al., 2006). In contrast to the canonical Ras proteins, constitutively active M-Ras has a low transforming activity and is rarely mutated in human cancer (Quilliam et al., 1999); however, gain-of-function mutations in M-RAS have been iden- tified in patients with Noonan syndrome (Higgins et al., 2017). Notably, mutations in one of the distinct effectors of M-RAS, the SHOC2 scaffold, have also been detected in Noonan patients (Cordeddu and Di, 2009; Hannig et al., 2014), and, likewise, Shoc2 has been implicated in cell migratory events (Young et al., 2013; Kaduwal et al., 2015; Jeoung et al., 2016).

Subsequent biochemical studies have shown that the direct binding of Shoc2 to active GTP-bound M-Ras allows the Shoc2 scaffold to nucleate a ternary complex consisting of active M-Ras, Shoc2 and the catalytic subunit of PP1 (PP1c) (Rodriguez-Viciana et al., 2006). In RTKmediated signaling, the M-Ras/Shoc2/PP1c ternary com- 
plex functions to dephosphorylate a negative regulatory 14-3-3 binding site on the Raf kinases, which promotes Raf binding to the canonical Ras proteins and facilitates ERK cascade activation (Rodriguez-Viciana et al., 2006; Matsunaga-Udagawa et al., 2010; Galperin et al., 2012). This complex has been implicated in the dynamic regulation of ERK activity and cell polarity in some cancer cell lines (Young et al., 2013). Moreover, M-Ras/Shoc2 signaling contributes to junction turnover by modulating the Cdh1/p120-catenin interaction and, in turn, the junctional expression of Cdh1. The regulatory effect of the MRas/Shoc2 complex was mediated at least in part through the phosphor-regulation of $\mathrm{p} 120$-catenin and required downstream ERK cascade activation (Kota et al., 2019).

Compaction appears to occur in all mammalian embryos but at different cell cycles. In the pig, compaction and cell polarization occur more gradually than in the mouse and coincide with relocation of $\mathrm{CDH} 1$ to contact sites, the process not completing long before blastocyst formation (Reima et al., 1993). In the developing embryo CDH1 is a key player during morula compaction and $C D H 1$ null embryos die early during embryogenesis as development of the blastocyst and trophectoderm is impaired (Larue et al., 1994; Riethmacher et al., 1995).

To further elucidate the biological functions of the MRAS on porcine embryonic compaction, we investigated the mechanism by which M-RAS and CDH1 contribute to the regulation of compaction.

\section{MATERIALS AND METHODS}

\section{Reagents}

Unless otherwise noted, all chemicals were purchased from Sigma-Aldrich (St. Louis, MO, USA).

\section{Oocyte collection and in vitro maturation (IVM)}

All animal studies were performed in strict accordance with the institutional guideline and prior approval from the Institutional Animal Care and Use Committee (IACUC) of the Chungbuk National University, Republic of Korea.

Prepubertal porcine ovaries were transported from a local abattoir (Farm Story Hannang, Chungwon, Chungbuk, Republic of Korea) within one hour of harvest. Cumulusoocyte complexes (COCs) were aspirated from 3-6 mm of ovarian follicles using 18-gauge needles attached to a 10$\mathrm{mL}$ syringe. High-density cumulus oocytes were collected and washed three times with HEPE-PVA medium (HEPES medium supplemented with $0.01 \%$ polyvinyl alcohol). After washing, $60-80$ COCs were cultured in $500 \mathrm{~mL}$ of IVM medium consist of M-199 (Invitrogen, Carlsbad, CA) containing $20 \mathrm{ng} / \mathrm{mL}$ epidermal growth factor, $1 \mathrm{~g} / \mathrm{mL}$ insulin, $75 \mathrm{~g} / \mathrm{mL}$ kanamycin, $0.91 \mathrm{mM}$ Na pyruvate, $0.57 \mathrm{mM}$ L-cysteine, $10 \%$ (v/v) porcine follicular fluid, $0.5 \mu \mathrm{g} / \mathrm{mL}$ follicle stimulating hormone (FSH), and $0.5 \mu \mathrm{g} / \mathrm{mL}$ luteinizing hormone $(\mathrm{LH})$ at $38.5^{\circ} \mathrm{C}$ in an atmosphere containing $5 \% \mathrm{CO}_{2}$ at $100 \%$ humidity.

\section{Parthenogenetic activation and in vitro culture (IVC)}

For parthenogenetic activation, mature oocytes were denuded by gentle pipetting in $1 \mathrm{mg} / \mathrm{mL}$ hyaluronidase until all the cumulus cells were removed from around the oocyte. Oocytes were then washed three times in PBS-BSA (DPBS added in 0.1\% BSA) and activated using an Electro Cell Manipulator 2001 (BTX, Inc., San Diego, CA, USA). The electric pulse was stimulated at $110 \mathrm{~V} / \mathrm{cm}$ twice for $60 \mu \mathrm{sec}$ in $280 \mathrm{mM}$ mannitol medium supplemented with $0.1 \mathrm{mM} \mathrm{CaCl}_{2}, 0.05 \mathrm{mM} \mathrm{MgCl}_{2}, 0.01 \%$ polyvinyl alcohol (PVA, w/v), and $0.5 \mathrm{mM} 4$-(2-hydroxyethyl) piperazine1 -ethanesulfonic acid. Activated oocytes were treated in PZM- 5 medium containing $7.5 \mu \mathrm{g} / \mathrm{mL}$ cytochalasin B in an incubator for $3 \mathrm{~h}$ to suppress extrusion of the pseudo second polar body. Embryos were thoroughly washed and cultured in bicarbonate buffered PZM- 5 supplemented with $4 \mathrm{mg} / \mathrm{mL} \mathrm{BSA}$ in 4 -well plates for $6 \mathrm{~d}$ at $38.5^{\circ} \mathrm{C}$ and $5 \% \mathrm{CO}_{2}$. Two-cell and 4-cell cleavage rate and morula and blastocyst formation rate were examined, respectively, at $24,48,96$, and $144 \mathrm{~h}$ after activation. To determine the total cell number, day- 6 blastocysts were randomly collected and stained with $10 \mathrm{mg} / \mathrm{mL}$ Hoechst 33342 in PBS for $5 \mathrm{~min}$.

\section{M-RAS double-stranded RNA preparation}

To prepare $M-R A S$ double-stranded RNA (dsRNA), $M$ $R A S$ was amplified using a pair of primers (Table 1) containing the T7 promoter sequence. The purified PCR products were then used to synthesize dsRNA with the MEGAscript T7 Kit (AM1333; Thermo Fisher Scientific) according to the manufacturer's instructions. After in vitro transcription, dsRNA was treated with DNase I and RNase A to remove the DNA template and any single-stranded RNAs, followed by purification with phenol-chloroform extraction and isopropyl alcohol precipitation. The puri- 
Table 1. Summary of PCR primers

\begin{tabular}{|c|c|c|c|c|}
\hline \multirow{2}{*}{ Gene } & \multicolumn{2}{|c|}{ Primer sequence, 5’-3’ } & \multirow{2}{*}{$\begin{array}{c}\text { Product } \\
\text { length (bp) }\end{array}$} & \multirow{2}{*}{ Used for } \\
\hline & Forward & Reverse & & \\
\hline \multirow[t]{4}{*}{ M-RAS } & gaattaatacgactcactatagggagaaacctccccacatacaagc & gaattaatacgactcactatagggagacagcaaagccagaccctatc & 868 & $\begin{array}{c}\text { M-RAS } \\
\text { knockdown }\end{array}$ \\
\hline & gaactcttccagCCCCGCCGTGTCCAGAAC & tcctcgcccttgctcaccatgctagcCAATATCACGCACTGCAGTTTG & 624 & Active \\
\hline & cgctcaactttggcagatctgaattcCATGGCAACCAGTGCCGTCC & acggcggggctgGAAGAGTTCAGCGCCATGC & & $\mathrm{M}-\mathrm{RAS}^{\mathrm{Q} 71 \mathrm{~L}}$ \\
\hline & ttgcccaccttctctcagag & ggccacctgtgtagacaatg & 278 & $\begin{array}{c}\text { mRNA } \\
\text { quantification }\end{array}$ \\
\hline
\end{tabular}

fied dsRNA was dissolved in RNase-free water and stored at $-80^{\circ} \mathrm{C}$ until use.

\section{Cloning and in vitro mRNA synthesis}

The open reading frames of pig $M-R A S$ (Table 1) were amplified from cDNA prepared from pig embryos. Amplified PCR products were subcloned into the pRN3 vector, and in vitro transcription was performed with a MEGAscript T3 Kit (Thermo Fisher Scientific).

\section{Microinjection}

For knockdown or overexpression experiments, $M-R A S$ dsRNA or M-RAS cRNA was microinjected into the cytoplasm of a parthenogenetically activated oocyte using an Eppendorf Femto-Jet (Eppendorf, Hamburg, Germany) and Nikon Diaphot Eclipse TE300 inverted microscope (Nikon, Tokyo, Japan) equipped with a Narishige MM0202N hydraulic 3-dimensional micromanipulator (Narishige, Amityville, NY, USA). After injection, oocytes were cultured in PZM-5 medium. The control group was microinjected with green fluorescent protein dsRNA.

\section{Immunofluorescence and confocal microscopy}

After washing 3 times with PBS and PVA, embryos were fixed in $3.7 \%$ paraformaldehyde for $30 \mathrm{~min}$ at room temperature, permeabilized with PBS and PVA containing $0.5 \%$ Triton $\mathrm{X}-100$ at room temperature for $30 \mathrm{~min}$ and incubated in PBS and PVA containing 1.0\% BSA at room temperature for $1 \mathrm{~h}$. These embryos were incubated overnight at $4^{\circ} \mathrm{C}$ with anti-M-RAS (1:100,14213-1-AP; Proteintech), anti-CDH1 (1:100, 610182, BD Biosciences), or anti-ZO1 (1:100; 33-9100, Invitrogen) diluted in blocking solution. After washing 3 times with PBS and PVA, the embryos were incubated at room temperature for $1 \mathrm{~h}$ with goat anti-rabbit IgG, rabbit anti-goat IgG, or antimouse IgG. The oocytes and embryos were stained with
$10 \mathrm{mg} / \mathrm{mL}$ Hoechst 33342 for $5 \mathrm{~min}$, washed 3 times with PBS and PVA, mounted onto slides, and examined using a confocal microscope (Zeiss LSM 710 Meta). Images were processed using Zen software (v.8.0; Zeiss).

\section{Real-time RT-PCR}

Embryos were collected, and mRNA was extracted from a pool of 30 embryos per group using the DynaBeads mRNA Direct Kit (61012; Thermo Fisher Scientific) according to the manufacturer's instructions. cDNA was obtained by reverse transcription of mRNA using the Oligo (deoxythymine) 20 primer and SuperScript III Reverse Transcriptase (Thermo Fisher Scientific). Amplification was conducted as follows: $95^{\circ} \mathrm{C}$ for 3 min followed by 40 cycles of $95^{\circ} \mathrm{C}$ for $15 \mathrm{~s}, 60^{\circ} \mathrm{C}$ for $25 \mathrm{~s}, 72^{\circ} \mathrm{C}$ for $10 \mathrm{~s}$, and final extension at $72^{\circ} \mathrm{C}$ for $5 \mathrm{~min}$. Target genes was $M$-RAS. Glyceraldehyde-3-phosphate dehydrogenase $(G A P D H)$ was used as a reference gene. The primers used to amplify each gene are shown in Table 1. mRNA quantification data were analyzed using the $2^{-\Delta \Delta C t}$ method (Livak and Schmittgen, 2001).

\section{Western blot analysis}

A total of 100 porcine embryos per group were placed in 1-time SDS sample buffer and heated at $98^{\circ} \mathrm{C}$ for 10 min. Proteins were separated by SDS-PAGE and transferred to polyvinylidene fluoride membranes. Next, the membranes were blocked in Tris buffered saline containing $0.1 \%$ Tween 20 and $5 \%$ nonfat milk for $1 \mathrm{~h}$ and then incubated at $4^{\circ} \mathrm{C}$ overnight with anti-M-RAS, ERK, pERK, CHD1 or $\beta$-tubulin, wash three time by TBST. Then incubated at room temperature for $1 \mathrm{~h}$ with horseradish peroxidase-conjugated goat anti-mouse IgG or goat antirabbit IgG (1:20000; Santa Cruz Biotechnology). Membranes were developed by SuperSignal West Femto Trial Kit (34094, Thermo Scientifc, Waltham, MA, USA). Blots 
were visualized by a charge-coupled device camera and UviSoft software (Uvitec, Cambridge, United Kingdom).

\section{Statistical analysis}

Each experiment was repeated at least 3 times, and representative images are shown in figures. All data were subjected to Student's t test. All percentage data were subjected to arcsine transformation prior to statistical analysis and presented as the means 6 SEM. Significance was set at a value of $p<0.05$. All calculations were performed using SPSS software v.19 (IBM SPSS, Chicago, IL, USA). All box plots show the median (line), mean (+), and 25 th and 75 th percentiles (boxes), and the whiskers show the minimum to maximum values.

\section{RESULTS}

\section{Expression patterns of M-RAS during porcine embryo development}

We evaluated the expression and subcellular location of M-RAS at different stages during porcine embryo development (Fig. 1). M-RAS was expressed in the cytoplasm at zygote stage and highly expressed on the membrane from 2-cell stage until morula stage. The signal was detected on the nucleus from blastocyst (Fig. 1A). Moreover, the protein expression was decreased during preimplanta-
A
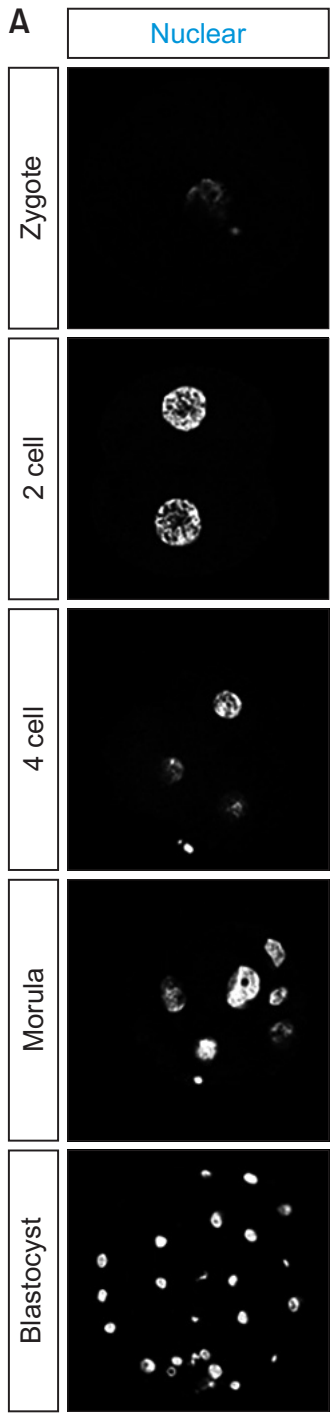
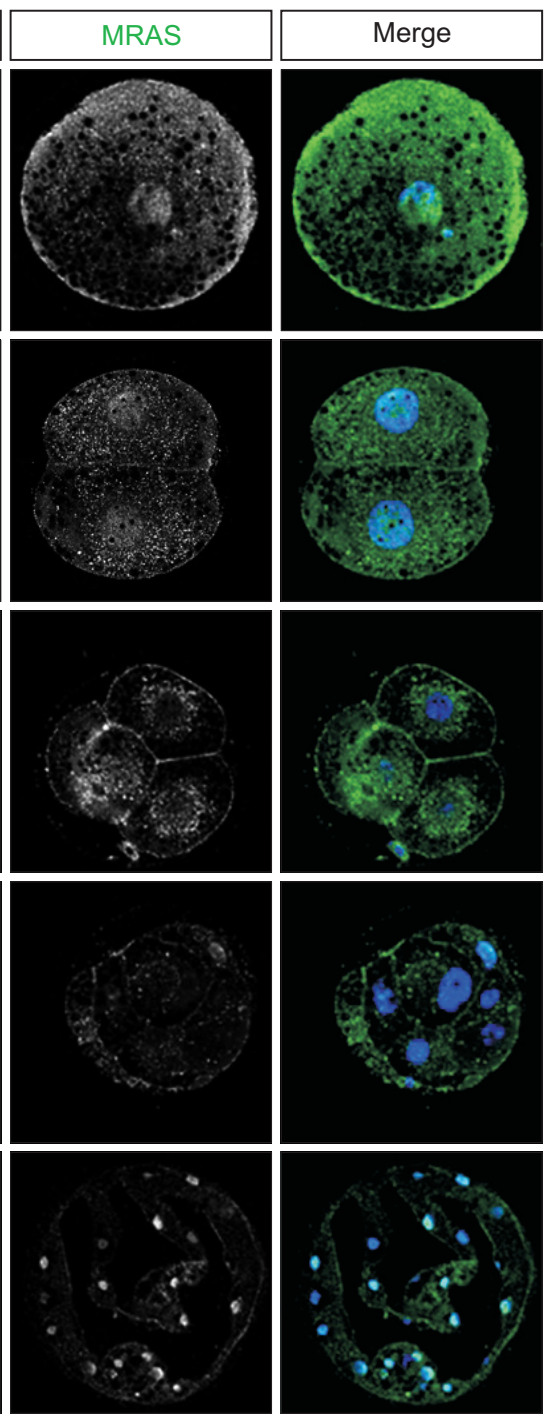

Fig. 1. Expression patterns of M-RAS during porcine embryo development. (A) Immunofluorescence images of M-RAS at different stages of porcine embryos. (B) Intensity of M-RAS at different stages. ${ }^{*} p<0.05$; ${ }^{* *} p<0.01$. (C) The mRNA expression level of $M-R A S$ performed by qPCR at different stages. 
tion development (Fig. 1B). The mRNA expression level of $M-R A S$ was detected by qPCR. $M-R A S$ was maternally expressed in MII oocytes. Thereafter, M-RAS expression decreased and remained at a low level until blastocyst (Fig. 1C).

\section{Effects of M-RAS knockdown on early porcine embryonic development}

To investigate the role of $\mathrm{M}$-Ras in compaction during porcine embryo development, $M-R A S$ double-stranded RNA (dsM-RAS) was injected into porcine parthenotes, which were then cultured in vitro for 6 days (Fig. 2). The blastocyst rates were calculated. M-RAS knock-down (MRAS KD) embryos displayed a significantly lower developmental rate than control embryos, even though no difference at 2-cell stage (Fig. 2A, 2B). Compared to controls, the mRNA expression level of $M-R A S \mathrm{KD}$ embryos was decreased at both 2-cell stage and blastocyst stage (Fig. 2C, 2D), and a lower level of M-RAS protein as revealed by western blotting (Fig. 2E).
The active M-RAS regulates cell-cell adhesion by modulating the $\mathrm{E}$-cadherin which correlates with ERK cascade activation

To more directly assess the role of M-RAS in regulating intercellular adhesion, we examined whether the presence or absence of M-RAS had any effects on E-cadherin localization in different stages of embryos (Fig. 3). In $M-$ RAS KD embryos, the decrease in cell-cell adhesion coincided with a lower expression of $\mathrm{E}$-cadherin shown by immune fluorescence and western blotting (Fig. 3A, 3B). However, no detectable change in ZO-1 (also known as tight junction protein-1) was present in $M-R A S \mathrm{KD}$ porcine embryos (Fig. 3C). In addition, the phosphorylation level of ERK was significantly higher than M-RAS KD embryos.

\section{Overexpression of M-RAS rescues the disrupt of} embryonic compaction after M-RAS knockdown

To confirm that the role of the M-RAS on embryonic compaction, we first produced the cRNA of activated M-
A
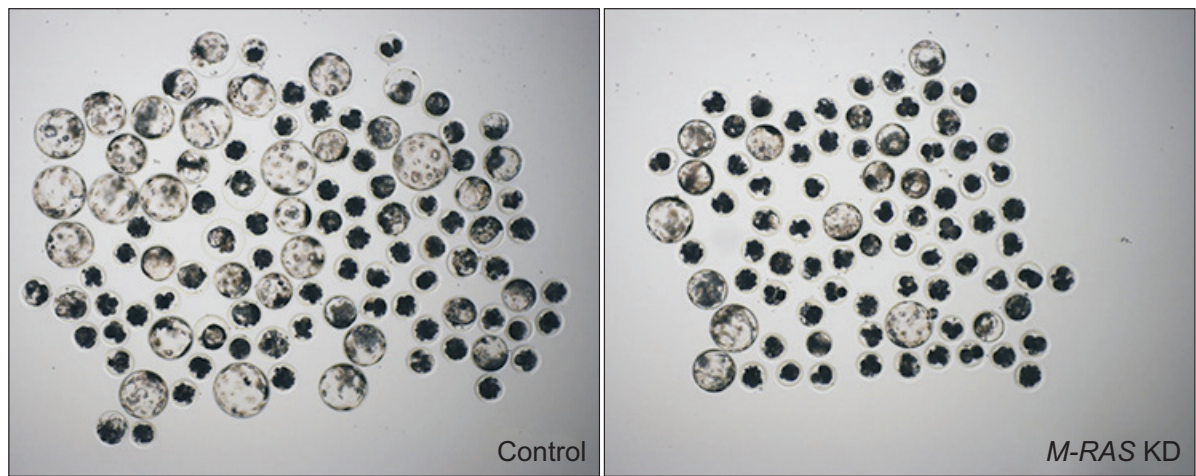

C

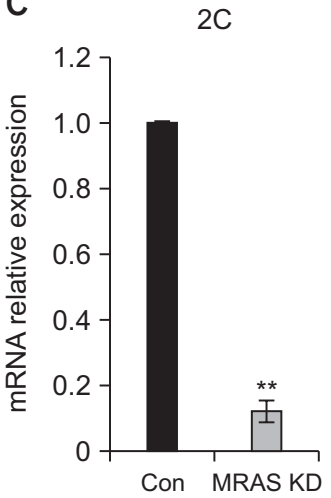

D

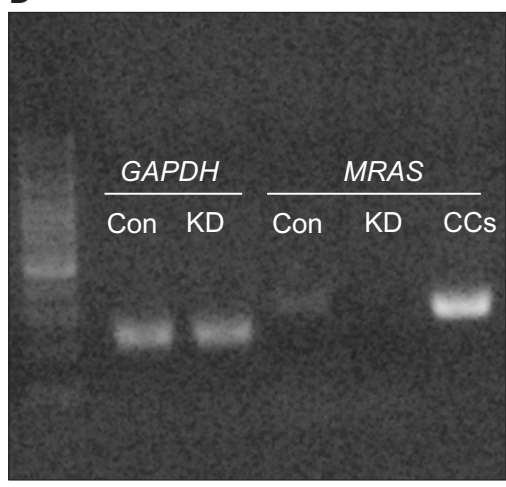

$\mathrm{BL}$

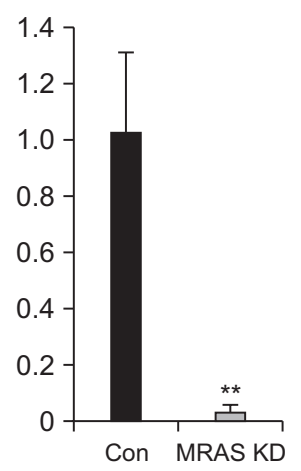

B

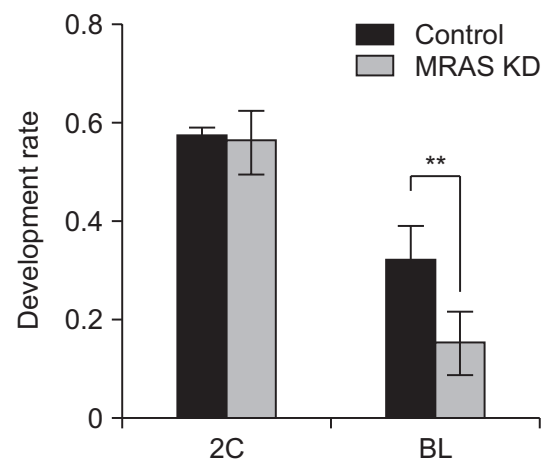

E

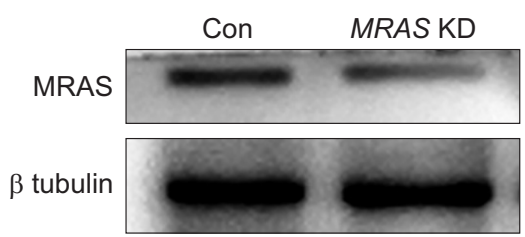

Fig. 2. M-RAS is required for porcine embryo preimplantation development. (A) Image of blastocyst after dsRNAs injection (con, dseGFP). (B) Developmental abilities of embryos after dsRNAs injection. (C-D) The mRNA expression level of M-RAS performed by qPCR at 2-cell stage (C) and blastocyst stage (D) (con, dseGFP; KD, M-RAS KD; CCs, cumulus cells). (E) Protein expression of M-RAS after dsRNAs injection performed by western blotting. ${ }^{* *} p<0.01$. 
A
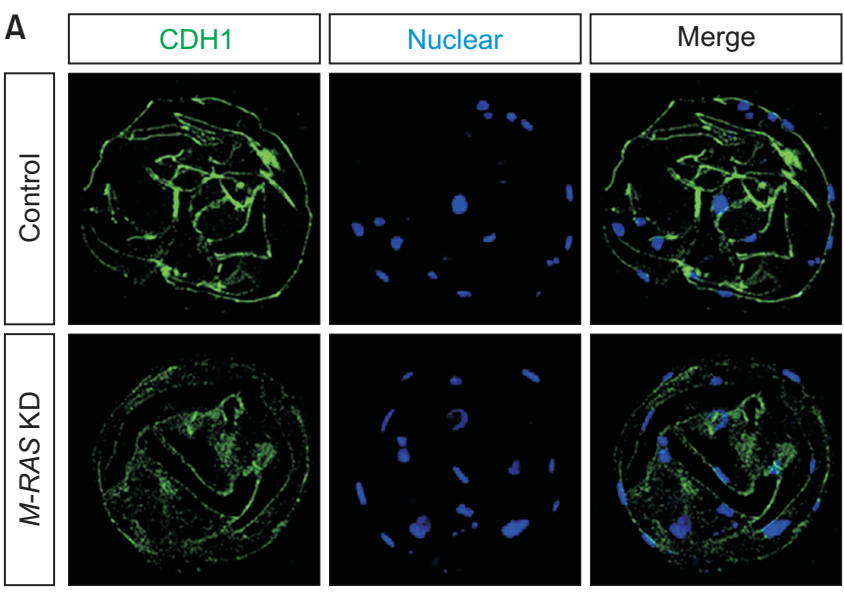

B

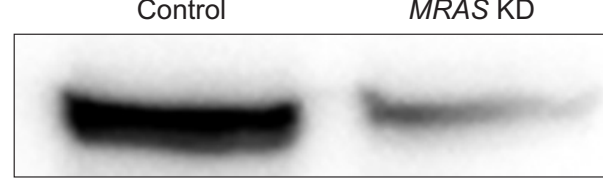

$\beta$ tubulin
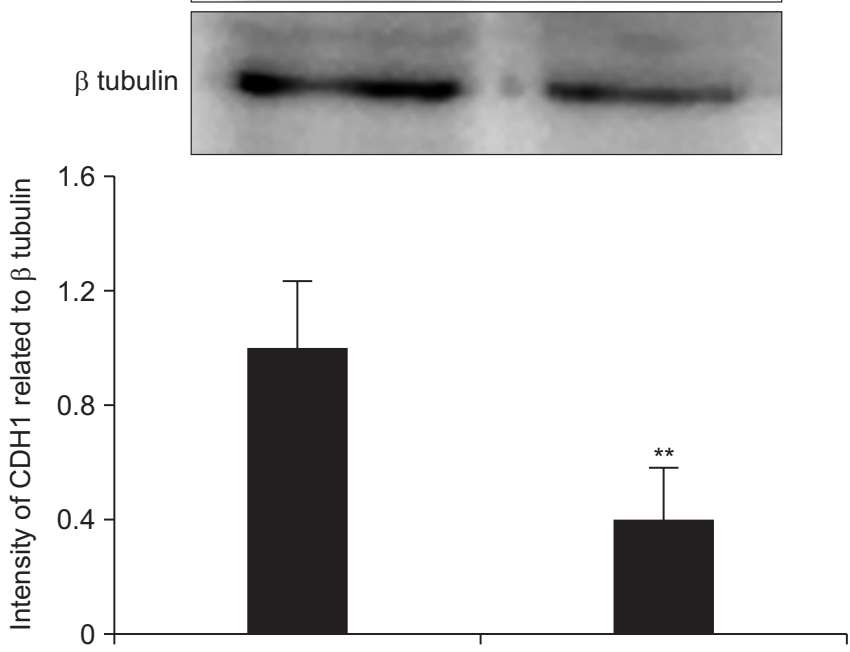

C
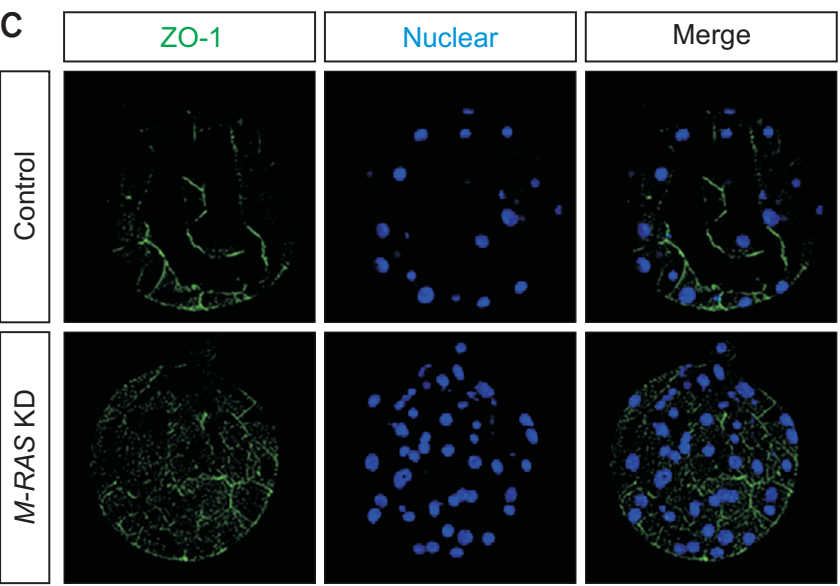

D
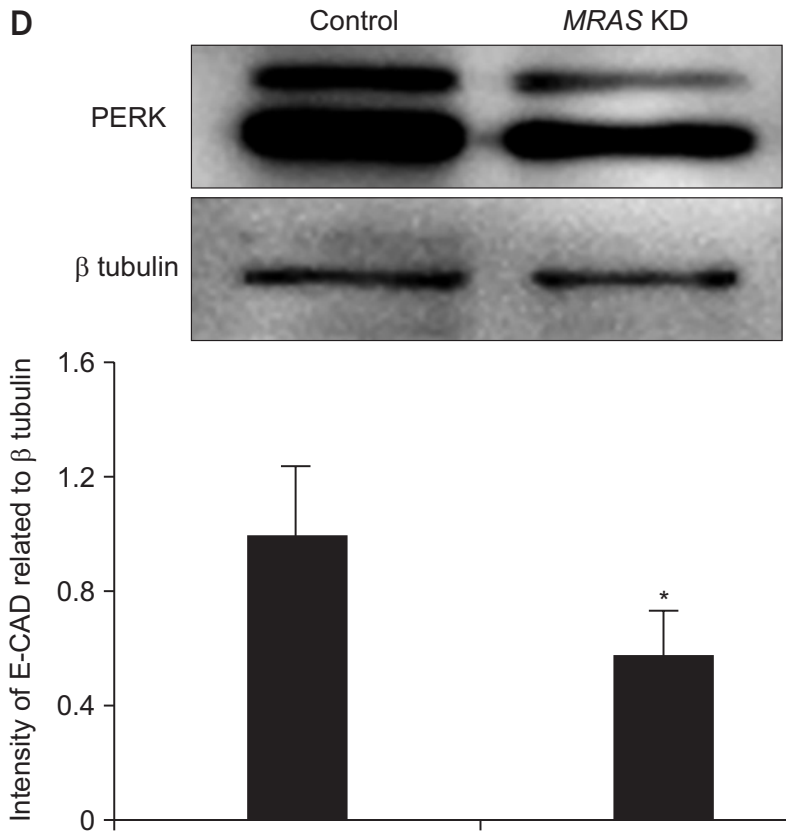

Fig. 3. M-RAS modulates the compaction through the effects on cell-cell junction. (A) Immunofluorescence images of CDH1 at blastocyst stage after dsRNAs injection. (B) Protein expression of CDH1 after dsRNAs injection performed by western blotting. (C) ZO-1 staining was detected on blastocyst embryos after dsRNAs injection. (D) The phosphorylation level of ERK was performed by western blotting. ${ }^{*} p<0.05 ;{ }^{* *} p<0.01$.

$\mathrm{RAS}^{\mathrm{Q} 71 \mathrm{~L}}$ and injected together with dsRNA of eGFP or $M$ $R A S$ to the zygote stage embryos. Compared to control embryos which were expressing activated M-RAS ${ }^{\mathrm{Q71L}}$, blastocyst rate was no significantly change in dsM-RAS and M-RAS ${ }^{\mathrm{Q} 71 \mathrm{~L}}$ injected embryos (Fig. 4A, 4B).

\section{DISCUSSION}

M-RAS was first identified as an effector of embryo compaction through its function as a positive regulator of growth factor mediated ERK cascade activation. M-RAS has variable expression throughout the body, with high expression in the heart, brain, breast, and ovaries. M-RAS encodes a 208-amino acid, membrane-associated protein which participates in Ras/MAPK pathway signaling.

M-RAS is a member of the Ras super family of proteins, which includes HRAS, KRAS, NRAS, Rit1, and RRAS (Aoki et al., 2005; Schubbert et al., 2006; Cirstea and Kdvorsky, 2010; Aoki et al., 2013; Flex et al., 2014). All Ras proteins belong to a class of small GTPases and cycle between an active GTP-bound state and an inactive, GDP-bound state. In the active, GTP-bound state, Ras proteins undergo a conformational change allowing binding to other effector proteins and participation in signaling cascades. 
A

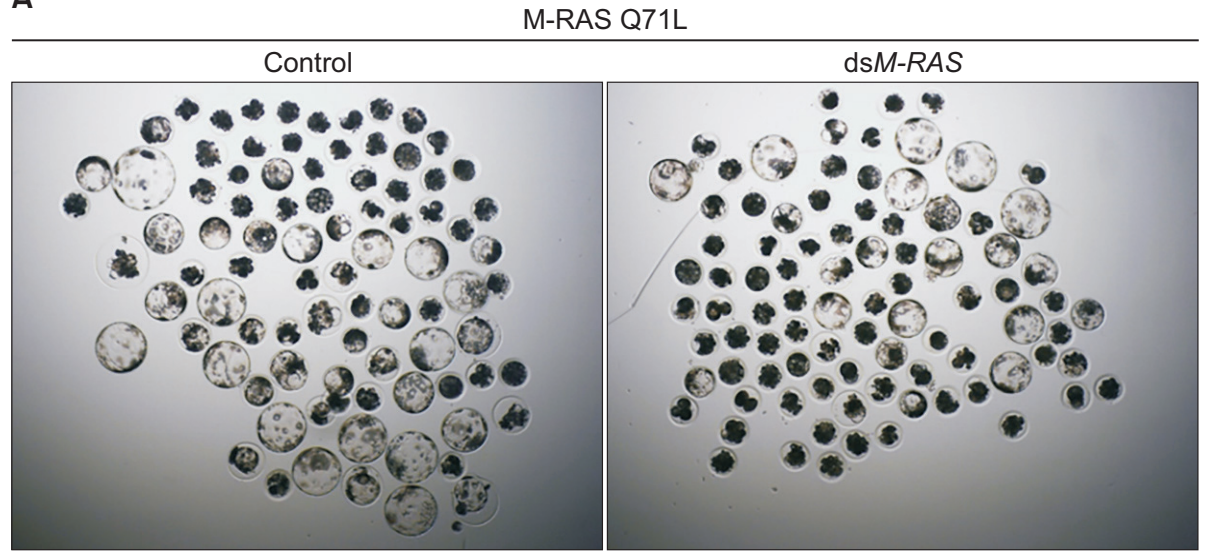

B

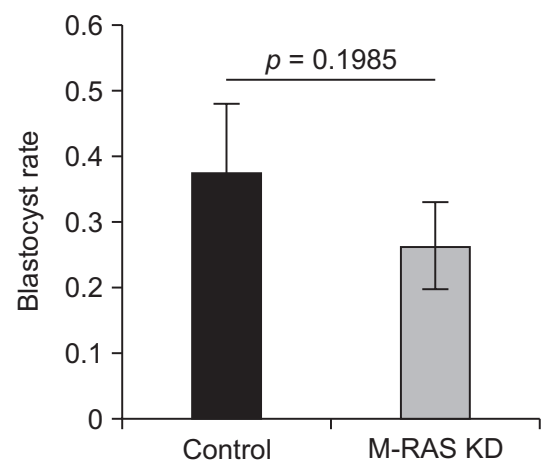

Fig. 4. Activated M-RAS rescued the defect after M-RAS KD. (A) Image of blastocyst after RNAs injection. (B) The blastocyst development rates after RNAs injection (con, dseGFP + M-RAS ${ }^{071 L} ; M-R A S K D, d S M-R A S+M-R A S^{071 L}$ ).

The intrinsic Ras GTPase hydrolyzes Ras-GTP back to Ras-GDP, with the aid of GTPase-activating proteins (GAPs), to terminate activity and signaling.

M-RAS specifically functions within the Ras/MAPK pathway by forming a ternary complex with SHOC2 and PP1. The formation of this complex localizes SHOC2 and PP1 to the cell membrane where SHOC2 acts as a regulatory subunit of PP1c, targeting it to specifically dephosphorylate the P-S259 inhibitory site of RAF1 kinase. The removal of this inhibitory phosphate stimulates Raf1 activity and, thereby, activity of downstream MAPK pathway signaling (Rodriguez-Viciana et al., 2006). M-RAS, therefore, makes a critical contribution to ERK activation by receptor tyrosine kinases and downstream MAPK signaling (Young et al., 2013). Our results suggest that M-RAS regulate the cell adhesion proteins through the activity of this M-RAS/SHOC2/PP1C complex.

Elevated expression of E-cadherin at adhesion junctions is known to increase cell-cell adhesiveness, and binding of p120-catenin to the juxta membrane domain of E-cadherin promotes the surface stability of E-cadherin by preventing its endocytosis and degradation. In particular, we found that E-CADHEREN protein level of $M-R A S$ $\mathrm{KD}$ embryos was reduced whereas interaction between E-cadherin and p120-catenin previously reported to increase cell-cell adhesiveness was increased (Kota et al., 2019). In this study, we demonstrate that M-RAS transduces signal specific to the embryonic program including preimplantation development and compaction.

\section{CONFLICTS OF INTEREST}

No potential conflict of interest relevant to this article was reported.

\section{ACKNOWLEDGEMENTS}

This work was financially supported by the National Research Foundation (NRF) of Korea grant funded by the Korea government (ministry of education science and technology) (No. 2018R1A2B6001173) and Research Year of Chungbuk National University in 2019, Republic of Korea.

\section{AUTHOR CONTRIBUTIONS}

Xiang-Shun Cui, Dongjie Zhou designed the experiment. Dongjie Zhou conducted the experiments, analyzed the results, and wrote the article. Yingjie Niu helped with the analyses of the results and figures. Xiang-Shun Cui revised the manuscript.

\section{AUTHOR'S POSITION AND ORCID NO.}

\author{
D Zhou, PhD Student, \\ https://orcid.org/0000-0002-4065-0732 \\ Y Niu, Post-Doc., \\ https://orcid.org/0000-0003-1829-1718 \\ XS Cui, Professor, \\ https://orcid.org/0000-0001-6180-6401
}




\section{REFERENCES}

Aoki Y, Niihori T, Banjo T, Okamoto N, Mizuno S, Kurosawa K, Ogata T, Takada F, Yano M, Ando T, Hoshika T, Barnett C, Ohashi H, Kawame H, Hasegawa T, Okutani T, Nagashima T, Hasegawa S, Funayama R, Nagashima T, Nakayama K, Inoue S, Watanabe Y, Ogura T, Matsubara Y. 2013. Gain-of-function mutations in RIT1 cause Noonan syndrome, a RAS/MAPK pathway syndrome. Am. J. Hum. Genet. 93:173-180.

Aoki Y, Niihori T, Kawame H, Kurosawa K, Ohashi H, Tanaka Y, Filocamo M, Kato K, Suzuki Y, Kure S, Matsubara Y. 2005. Germline mutations in HRAS proto-oncogene cause Costello syndrome. Nat. Genet. 37:1038-1040.

Cirstea IC, Kutsche K, Dvorsky R, Gremer L, Carta C, Horn D, Roberts AE, Lepri F, Merbitz-Zahradnik T, König R, Kratz CP, Pantaleoni F, Dentici ML, Joshi VA, Kucherlapati RS, Mazzanti L, Mundlos S, Patton MA, Silengo MC, Rossi C, Zampino G, Digilio C, Stuppia L, Seemanova E, Pennacchio LA, Gelb BD, Dallapiccola B, Wittinghofer A, Ahmadian MR, Tartaglia M, Zenker M. 2010. A restricted spectrum of NRAS mutations causes Noonan syndrome. Nat. Genet. 42:27-29.

Cordeddu V, Di Schiavi E, Pennacchio LA, Ma'ayan A, Sarkozy A, Fodale V, Cecchetti S, Cardinale A, Martin J, Schackwitz W, Lipzen A, Zampino G, Mazzanti L, Digilio MC, Martinelli S, Flex E, Lepri F, Bartholdi D, Kutsche K, Ferrero GB, Anichini C, Selicorni A, Rossi C, Tenconi R, Zenker M, Merlo D, Dallapiccola B, Iyengar R, Bazzicalupo P, Gelb BD, Tartaglia M. 2009. Mutation of SHOC2 promotes aberrant protein N-myristoylation and causes Noonan-like syndrome with loose anagen hair. Nat. Genet. 41:1022-1026.

Flex E, Jaiswal M, Pantaleoni F, Martinelli S, Strullu M, Fansa EK, Caye A, De Luca A, Lepri F, Dvorsky R, Pannone L, Paolacci S, Zhang SC, Fodale V, Bocchinfuso G, Rossi C, BurkittWright EM, Farrotti A, Stellacci E, Cecchetti S, Ferese R, Bottero L, Castro S, Fenneteau O, Brethon B, Sanchez M, Roberts AE, Yntema HG, Van Der Burgt I, Cianci P, Bondeson ML, Cristina Digilio M, Zampino G, Kerr B, Aoki Y, Loh ML, Palleschi A, Di Schiavi E, Carè A, Selicorni A, Dallapiccola B, Cirstea IC, Stella L, Zenker M, Gelb BD, Cavé H, Ahmadian MR, Tartaglia M. 2014. Activating mutations in RRAS underlie a phenotype within the RASopathy spectrum and contribute to leukaemogenesis. Hum. Mol. Genet. 23:4315-4327.

Galperin E, Abdelmoti L, Sorkin A. 2012. Shoc2 is targeted to late endosomes and required for Erk1/2 activation in EGFstimulated cells. PLoS One 7:e36469.

Gao X, Satoh T, Liao Y, Song C, Hu CD, Kariya Ki K, Kataoka T. 2001. Identification and characterization of RA-GEF-2, a Rap guanine nucleotide exchange factor that serves as a downstream target of M-Ras. J. Biol. Chem. 276:42219-42225.

Hannig V, Jeoung M, Jang ER, Phillips JA 3rd, Galperin E. 2014. A novel SHOC2 variant in Rasopathy. Hum. Mutat. 35:12901294.

Herrmann C, Horn G, Spaargaren M, Wittinghofer A. 1996. Dif- ferential interaction of the ras family GTP-binding proteins H-Ras, RaplA, and R-Ras with the putative effector molecules Raf kinase and Ral-guanine nucleotide exchange factor. J. Biol. Chem. 271:6794-6800.

Higgins EM, Bos JM, Mason-Suares H, Tester DJ, Ackerman JP, MacRae CA, Sol-Church K, Gripp KW, Urrutia R, Ackerman MJ. 2017. Elucidation of MRAS-mediated Noonan syndrome with cardiac hypertrophy. JCI Insight 2:e91225.

Jeoung M, Jang ER, Liu J, Wang C, Rouchka EC, Li X, Galperin E. 2016. Shoc2-tranduced ERK1/2 motility signals--novel insights from functional genomics. Cell. Signal. 28:448-459.

Kaduwal S, Jeong WJ, Park JC, Lee KH, Lee YM, Jeon SH, Lim YB, Min DS, Choi KY. 2015. Sur8/Shoc2 promotes cell motility and metastasis through activation of Ras-PI3K signaling. Oncotarget 6:33091-33105.

Kimmelman A, Tolkacheva T, Lorenzi MV, Osada M, Chan AM. 1997. Identification and characterization of R-ras3: a novel member of the RAS gene family with a non-ubiquitous pattern of tissue distribution. Oncogene 15:2675-2685.

Kota P, Terrell EM, Ritt DA, Insinna C, Westlake CJ, Morrison DK. 2019. M-Ras/Shoc2 signaling modulates E-cadherin turnover and cell-cell adhesion during collective cell migration. Proc. Natl. Acad. Sci. U. S. A. 116:3536-3545.

Larue L, Ohsugi M, Hirchenhain J, Kemler R. 1994. E-cadherin null mutant embryos fail to form a trophectoderm epithelium. Proc. Natl. Acad. Sci. U. S. A. 91:8263-8267.

Livak KJ and Schmittgen TD. 2001. Analysis of relative gene expression data using real-time quantitative PCR and the 2(-Delta Delta C(T)) method. Methods 25:402-408.

Matsunaga-Udagawa R, Fujita Y, Yoshiki S, Terai K, Kamioka Y, Kiyokawa E, Yugi K, Aoki K, Matsuda M. 2010. The scaffold protein Shoc2/SUR-8 accelerates the interaction of Ras and Raf. J. Biol. Chem. 285:7818-7826.

Quilliam LA, Castro AF, Rogers-Graham KS, Martin CB, Der CJ, Bi C. 1999. M-Ras/R-Ras3, a transforming ras protein regulated by Sos1, GRF1, and p120 Ras GTPase-activating protein, interacts with the putative Ras effector AF6. J. Biol. Chem. 274:23850-23857.

Rebhun JF, Castro AF, Quilliam LA. 2000. Identification of guanine nucleotide exchange factors (GEFs) for the Rap1 GTPase. Regulation of MR-GEF by M-Ras-GTP interaction. J. Biol. Chem. 275:34901-34908.

Reima I, Lehtonen E, Virtanen I, Fléchon JE. 1993. The cytoskeleton and associated proteins during cleavage, compaction and blastocyst differentiation in the pig. Differentiation 54:35-45.

Riethmacher D, Brinkmann V, Birchmeier C. 1995. A targeted mutation in the mouse $\mathrm{E}$-cadherin gene results in defective preimplantation development. Proc. Natl. Acad. Sci. U. S. A. 92:855-859.

Rodriguez-Viciana P, Oses-Prieto J, Burlingame A, Fried M, McCormick F. 2006. A phosphatase holoenzyme comprised of Shoc2/Sur8 and the catalytic subunit of PP1 functions as an M-Ras effector to modulate Raf activity. Mol. Cell 22:217230. 
Schubbert S, Zenker M, Rowe SL, Böll S, Klein C, Bollag G, van der Burgt I, Musante L, Kalscheuer V, Wehner LE, Nguyen H, West B, Zhang KY, Sistermans E, Rauch A, Niemeyer CM, Shannon K, Kratz CP. 2006. Germline KRAS mutations cause Noonan syndrome. Nat. Genet. 38:331-336.

Young LC, Hartig N, Muñoz-Alegre M, Oses-Prieto JA, Durdu
S, Bender S, Vijayakumar V, Vietri Rudan M, Gewinner C, Henderson S, Jathoul AP, Ghatrora R, Lythgoe MF, Burlingame AL, Rodriguez-Viciana P. 2013. An MRAS, SHOC2, and SCRIB complex coordinates ERK pathway activation with polarity and tumorigenic growth. Mol. Cell 52:679-692. 